\title{
NURSING ROLES USE IT OR LOSE IT
}

SYLVIA-ANNE LOMBARD Dip Gen (S A) Dip Mid (S A) Dip N E (U.P.) B Cur (Ed et Adm.) (RAU) B Cur Hons (U.P.)

\section{OPSOMMING}

Verpleegdienste word gelewer om mense te help om hulle gesondheid te behou, siekte en gebrek te voorkom en om te herstel tot hulle volle potensiaal.

Verpleegrolle moet aangeleer word en die verpleegkundige moet in die beroepsrol gesosialiseer word. Hierin is die bydrae van rolmodelle en van die verpleegopvoeder van groot belang.

Die verpleegrol bestaan nie in isolasie nie maar in wisselwerking met dié van ander lede van die gesondheidspan.

\section{PREFACE}

\section{Earliest nurses}

The word nurse has a simple and noble origin. Ultimately derived from the verb to nourish, it connotes someone who supplies lifegiving comfort and support.

In history there are indications that the very earliest hospital nurses may have been men. From ancient India, Sanscrit records supply accounts of a highly developed system of medicine and surgery which included the establishment of hospitals. The Indian hospitals may have been the first examples of state medicine. They were staffed by doctors and nurses paid by government.

It was Christianity which specifically enjoined the care of the sick and suffering as a duty upon the faithful and as a means whereby they could gain grace. The late Roman Empire and the mediaeval period witnessed a great expansion of religious institutions in which the piety of the worshippers and the needs of patients could happily meet.

\section{ROLE THEORY}

A role is a set of behaviours performed among people or a social group which is learned. Role theory stresses relationship, not static be-

\section{Lecturer: Medunsa}

haviours. A role is a sequence of acts performed by a person to complement other roles.

In the multiprofessional health team, members function in complex, interactive, collaborative relationships. Each of the professions' have delineated roles and defined standards for how individuals in a particular role should act or behave.

\section{Nursing}

Nursing is concerned with the care of people and takes into account the wholeness of man. Generally nursing involves close, personal contact in a health care service directed toward maintaining and promoting health and helping persons to cope in the best way possible with the problems of daily living, illness, disability and death.

Nursing is becoming increasingly health-orientated although the care of the sick is still one of its important functions. The nursing role that once included a minimum of health teaching and counselling of patients and their families with regard to health maintenance is now gaining increased attention. ${ }^{2}$

Nursing is a continuous process offered through all of life. During health and sickness nursing services are offered to help consumers maintain health, prevent disease and disability and to restore them to their best ability.

A basis of nursing is a belief in the value and uniqueness of every human being. Competent nursing practice demonstrates the belief that a person's total health needs must be met in a manner that shows concern for his uniqueness.

\section{NURSING ROLE ACQUISI- TION}

Role expectations and behaviours may be learned through acquisition, training and practice of the new role. Some mechanisms for learning a new role include:

- role taking - the learner constructs the role of another in her imagination

- entering into various aspects of enacting the role:

Role playing - this is the lowest level of role enactment and involves acting the part of someone else in an attempt to understand the situation of that other person or acquire an understanding of relationships and action

Socio-drama - employs role playing but actors play the role not only to achieve understanding but to develop a solution to the problem

Simulation - involves both role playing and socio-drama along with gaming. Gaming adds the elements of competition, co-operation and conflict to increase the reality value of the experience.

Role acceptance may be said to exist when the practitioner sees herself as a member of the profession. ${ }^{4}$ The process of learning the role and art of nursing can be seen as involving two major tasks

* the mastery of theory, and the

* achievement of competence in practice.

Socialisation into nursing roles includes the processes of acquisition of

* attitudes

* values

* skills, and

* behavioral patterns

that satisfy the role expectations and role behaviors of the profession.

The process of socialisation of nurses in their new roles to assume the attitudes and values that govern their future professional role is known as professionalisation. 
Socialisation and resocialisation of nurses for professional nursing practice

From the perspective of the nursing profession, the fact that nursing practitioner roles are constantly evolving and changing requires that there be a continual redefinition of standards and sets of values and behavior expectations, as a mechanism for assuring the quality of the care that is to be delivered.

Such continual redefinition of role standards includes mechanisms for reviewing and monitoring the standard of care and the educational programs which prepare the practitioners.

\section{Existence of role models in the socialising system}

The existence of role models who hold high professional standards and are able to operationalise those standards in the work setting are crucial to nursing.

\section{The educator and nursing role acquisition}

Students are molded by both intent and unplanned circumstances operating in the college itself and in nursing practice settings. They are particularly influenced by the role behaviours and expectations of faculty members, but are also significantly affected by the expectations of the professional staff members that she encounters, as well as by fellow students and patients.

The conundrum of any nursing faculty is the future projection of nursing practice. Educators need to focus on the practice requirements during the professional life-time of the student.

\section{THE NURSE'S ROLE IN COM- PREHENSIVE HEALTH CARE}

Health care is the total of all services rendered by various health disciplines. It is comprehensive and continuing in nature.

A variety of health personnel work interdependently and collabo- ratively to help meet the needs of the persons who enter the health care system. ${ }^{2}$

Each group of professionals has specific skills and knowledge to offer the consumer of health care: The nurse offers care that helps an individual achieve and maintain health.

\section{Role dimensions of the nurse}

\section{* To promote health}

Health promotion includes the support and development of mental as well as physical health programs.

\section{* To prevent disease}

Several trends are apparent in preventive health care.

One is an attempt to identify early symptoms of chronic diseases. Preventive measures can then help to decrease the ravages of disability and physical deterioration long before they occur.

A second trend is interest in the health problems of the elderly in our population.

A third dimension is a marked increase in concern for environmental factors that may cause illness.

\section{* Detection and treatment of disease}

The detection and treatment of disease remain essential responsibilities of health practitioners. Traditionally the nurse's role has been one of caring for the ill, and that responsibility remains today. Through her observations and skills in carrying out and supervising nursing care, much of which is very complicated in nature, the nurse plays a critical role in the detection and treatment of disease.

The nurse also often assists in research programs, and in many instances her contributions have made it possible to move forward more rapidly in disease detection and treatment. ${ }^{2}$

\section{* Rehabilitation}

Although rehabilitation has been concerned primarily with restoring a disabled person to his best possible health, a much broader concept is accepted today: rehabilitation is an important aspect of all health care.

Rehabilitation begins with the earliest contact with any person receiving health care. It includes all elements of care and continues throughout the period of illness and thereafter until the person is restored to wellness. ${ }^{2}$

\section{Reciprocal roles}

A role does not exist in isolation, but is reciprocal to that of other persons in the health team. The physician's role is complementary to the nurse's role.

Over several years the nurse's role and the physician's role have both been changing in reciprocal fashions. For example, a paediatric nurse practitioner is doing more well baby examinations than she did previously and her physician partner fewer, focusing more on illness problems. This is a reciprocal relationship between the two role partners that continues to change.

\section{THE FUTURE}

Nurse educators should advocate a psycho-social orientation with the central theme of preventive health care underlying all strategies. Within this context, the role nurses will play in solving identifiable health problems and the steps taken, will determine the future roles and directions of nursing.

\section{FURTHER READINGS}

1. Maclean, L L Nursing in Contemporary Society Rout ledge and Kegan Paul London 1974

2. Wolff. L et al Fundamentals of Nursing: The humanities and sciences in nursing. I B Lippincott Philadelphta 1979

3. Johnson. S H High-risk parenting: nursing assessmem and strategies for the family at risk J B Lippincott Philadelphia 1979 .

4. N.L.N. Socialization and resocilization of nurses for professional nursing practice N.L.N. New York 1976

Folta. J R. el al A sociological framework for patien Folta, J R. ef al A sociological framew'ork
care John Wiley \& Sons. New York 1979.

6. Clark. C C Assernive skills for nurses, Contemporary Publishing Wakefield Massachusets 1978.

Abdellah. F G Nursing role in furure health care Vol 24. No 2 AORN Journal 1976

8. Benson. E.R. et al Communiry health and nursing pracrice Prentice Hall Englewood Cliffs 1976

9. Bullough, B et al Expanding Horizons for nurses Springer New York 1977.

10. Clausen. J Socialization and socien, Little Brown and Co. Boston 1968 . 